\title{
The Internal Security of Poland in 2018 - Key Changes and Events
}

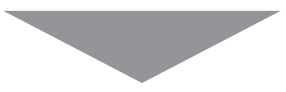

\begin{abstract}
The article presents the most important changes and events of the year 2018 in the field of Polish internal security. It analyses the changes concerning local security, police services, and secret services, and the creation of new security institutions. Despite a cabinet reshuffle, there could be no major changes in the field, as the Law and Justice party remained in power. The year 2018 was definitely one of continuation. Some of the most important events marked the finalization of previous declarations, and some were caused by the EU. The author argues that the events of 2018 confirm that Poland's internal security policy is characterized by stability and predictability.
\end{abstract}

Keywords: internal security of Poland, police services, secret services, surveillance, reforms

\section{INTRODUCTION}

Despite the cabinet reshuffle, which included the appointment of Mateusz Morawiecki as the new Prime Minister and Joachim Brudziński as the new Minister of the Interior and Administration, 2018 did not bring major changes in the field of Poland's internal security. The reforms initiated by the Law and Justice party after the 2015 parliamentary election have been continued, with a couple of important projects being finalized. The aim of this article is to present the most important changes and events of the year 2018 in the field of Polish internal 
security. The author focuses on analysing the activities of institutions subordinate to the government, as according to the Polish constitution the Council of Ministers is responsible for ensuring internal security and public order. The article is divided into four parts: it analyses the changes concerning local security (part 1), police services (part 2), secret services (part 3), and the creation of the new security institutions (part 4).

\section{LOCAL SECURITY}

Local security remains in the background of highly centralized public security policies. Since 2015 the Law and Justice-led government has been consistently restoring Police stations closed in the years 2007-2015. Its predecessor, the coalition of the Civic Platform and the Polish People's Party, closed 418 out of 817 stations, arguing that it would increase the effectiveness of Police operations, as more officers would be put on the ground, rather than sitting behind desks. In 2018, 25 stations were restored, and thus the number of reactivated stations exceeded 90. ${ }^{1}$ This means that the government began to approach its planned goal, which is to restore at least 100 stations. It was announced that it is willing to surpass this number, acting in accordance with the demand reported by voivodship Police commanders. ${ }^{2}$

At the same time, municipal guards, which are subordinate to and financed by local governments and complement Police activities at the local level, have been struggling with serious financial and staffing problems. The number of municipal guards in Poland has been decreasing since 2013 and this trend continued in 2018. Over the past six years, the number of municipal guards has decreased by nearly $20 \%$ and now stands at around $488^{3}$, which means that less than one in five municipalities (in Polish: gmina) has a municipal guard. The official statistics concerning municipal guards in 2018 have not yet been made public, but

1 Realizacja programu modernizacji służb mundurowych na półmetku, February 6, 2019, www. policja.pl/pol/aktualnosci/169260,Realizacja-Programu-Modernizacji-Sluzb-Mundurowychna-polmetku.html (accessed February 6, 2019).

2 Jarosław Zieliński: Do 2020 powstana 43 nowe posterunki policji, February 5, 2018, https://www. portalsamorzadowy.pl/wydarzenia-lokalne/jaroslaw-zielinski-do-2020-powstana-43-noweposterunki-policji,103665.html (accessed February 2, 2019).

3 M. Weber, Bezpieczeństwo to sprawa gminy, October 1, 2018, https://www.rp.pl/Prawodla-samorzadow/310039907-Bezpieczenstwo-to-sprawa-gminy.html\&cid=44\&template $=$ restricted (accessed February 2, 2019). 
regardless of what the exact figures are it is clear that the issue must be addressed in new regulations.

In the second half of 2018, a draft of an act dissolving municipal guards was submitted to the Sejm, but was resolutely rejected. Rather than closing it down, Polish politicians are interested in the institution's reform. Discussions regarding this have been under way for several years. Since $2012^{4}$ they have been conducted by the Inter-ministerial Team for Cooperation with Municipal (City) Guards, an auxiliary body of the Prime Minister. During the discussion a number of changes, concerning tasks, competences, staff and payroll issues, were proposed. Among them there is a proposal concerning the requirement of a two-thirds supermajority in the municipal council in favour of the dissolution of a guard unit. ${ }^{5}$ Another proposition is that the existence of a guard unit would be mandatory in cities with a population of more than 100,000. Also under consideration has been the question of whether to grant guards the right to make with their body cameras not only visual but also audio recordings of the people with whom they come into contact. ${ }^{6}$ At the end of 2018 , the Team was dissolved ${ }^{7}$, which marks the end of exploratory work. A project amending the act on municipal guards should be expected in 2019.

One of the areas in which municipal guards are becoming increasingly important is environmental protection, most notably preventive measures against smog. The improvement of air quality in Poland, which is among the worst in Europe, requires effective legal measures to enforce bans and restrictions on the combustion of solid fuels. On the $1^{\text {st }}$ of November, 2018, the new regulation on situations in which guards are entitled to impose fines came into force. ${ }^{8}$ Their ability to impose fines is no longer limited to catching red-handed somebody burning waste. The guards are now able to enforce anti-smog regulations passed

4 Zarządzenie Nr 69 Prezesa Rady Ministrów z dnia 29 sierpnia 2012 r. w sprawie powołania Międzyresortowego Zespołu do spraw Wspótpracy ze Strażami Gminnymi (Miejskimi), Monitor Polski 2012, item 631.

5 T. Żółciak, Minister Błaszczak szykuje rewolucję w strażach miejskich, Forsal.pl, June 28, 2017, forsal.pl/artykuly/1053813,minister-blaszczak-szykuje-rewolucje-w-strazach-miejskich.html (accessed February 20, 2018).

6 Grupa robocza do spraw kompetencji straży gminnych - rekomendacja, November 15, 2018.

7 Zarzadzenie nr 200 Prezesa Rady Ministrów z dnia 28 listopada 2018 r. w sprawie zniesienia niektórych organów pomocniczych Rady Ministrów i Prezesa Rady Ministrów, Monitor Polski 2018, item 1191.

8 Rozporzadzenie Ministra Spraw Wewnętrznych i Administracji z dnia 11 października 2018 r. zmieniające rozporzadzenie w sprawie wykroczeń, za które strażnicy straży gminnych sa uprawnieni do nakładania grzywien $w$ drodze mandatu karnego, Dziennik Ustaw 2018, item 1996. 
by local governments, which are introducing certain restrictions or prohibitions regarding fuel usage. Before this change, guards who reported violations of the anti-smog resolutions could only refer a case to the Police or apply to the court for the offending person to be punished. Long-lasting court proceedings made it difficult to be certain that punishment would be meted out. In addition, the courts sometimes lowered the sum of the fine, which made the punishment less severe. ${ }^{9}$ According to the changed ordinance, the guards now have the right to impose fines for offenses specified in "local law acts, laying down provisions for ensuring order, peace and public security, violation of which is punishable by a fine". ${ }^{10}$ This alone will not stop the trend towards the closing of guard units, but it proves that there are still a lot of tasks no other institution can perform.

\section{THE POLICE SERVICES}

\subsection{Budget, staffing, equipment and organizational changes}

In 2018, budget expenditures on public security and fire protection increased by 3\% compared to the previous year and amounted to almost PLN 14.994 billion. The Police remain the most expensive service, consuming $61 \%$ of the funds. Its 2017 budget was PLN 9.137 billion, while in 2018 it was PLN 9.292 billion. The budgets of other selected police services are presented in the chart 1.

In 2017, 2.6\% of the funds were allocated for investments, and in 2018 the figure was $2.9 \%{ }^{11}$ The change was minor but nonetheless noticeable, as it made the long-anticipated purchase of equipment possible. Particularly important purchases were made by the Police. In April 2018, the body camera pilot program, which had been underway since December 2017, came to a close. As its effect was considered satisfactory, in the middle of the year a tender for the supply of two thousand cameras was launched. ${ }^{12}$ In November the winner of the tender

9 Straż miejska może karać mandatem za łamanie uchwały antysmogowej, portal Samorządowy. pl, November 2, 2018, https://www.portalsamorzadowy.pl/prawo-i-finanse/straz-miejska-mo ze-karac-mandatem-za-lamanie-uchwaly-antysmogowej,116124.html (accessed December 12, 2018).

10 Rozporzadzenie Ministra Spraw Wewnętrznych i Administracji z dnia 11 października...

11 Ustawa budżetowa na rok 2017 z dnia 16 grudnia 2016 r., Dziennik Ustaw 2017, item 108; Ustawa budżetowa na rok 2018 z dnia 11 stycznia 2018 r., Dziennik Ustaw 2018, item 291.

12 Ponad dwa tysiace kamer osobistych trafi do policjantów, July 26, 2018, https://www.policja. $\mathrm{pl} / \mathrm{pol} /$ aktualnosci/161930,Ponad-dwa-tysiace-kamer-osobistych-trafi-do-policjantow.html (accessed February 2, 2019). 
was selected ${ }^{13}$ and the delivery of cameras to Police units has begun. A month later the Police granted the tender for delivery of eight light armoured personnel carriers. $^{14}$

Figure 1: The comparison of selected police services' budgets in 2017-2018 (in PLN millions)

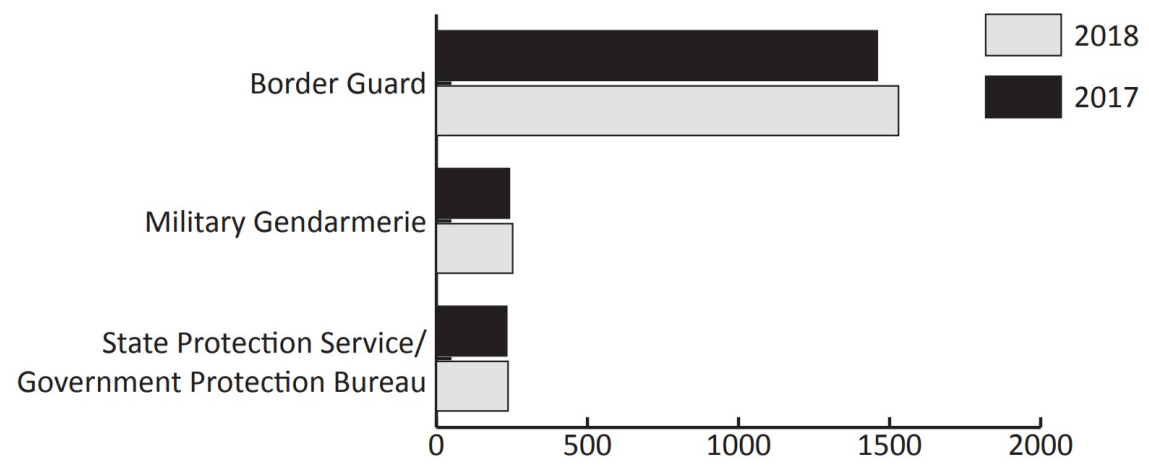

Source: Ustawa budżetowa na rok 2017...; Ustawa budżetowa na rok 2018...

Another important purchase made by the Police was of two S-70i Black Hawk helicopters, intended for the Bureau of Anti-terrorist Operations. The contract was signed in May, and the helicopters, both assembled in the Polish city of Mielec, were handed over to the Police in November. ${ }^{15}$ The date of delivery of the third machine is set for March $2019^{16}$, and the purchase of two more is planned. The three Black Hawks are the beginning of the process of reconstruction of the Polish Police fleet. Joachim Brudziński, Minister of the Interior and Administration, said that this was a necessity, as "the oldest helicopter in the Police is 47 years old, and the youngest -13 ". ${ }^{17}$ Also, several hundred cars are on the list of

13 203/CUT/18/EJ/PMP, przetargi.policja.pl/zp/archiwum-1/2018/161673,203Cut18EJPMP. html (accessed February 12, 2019).

14 272/CTR/18/TJ/PMP, przetargi.policja.pl/zp/postepowania-o-zamowie/164959,272Ctr18TJP MP.html (accessed February 12, 2019).

15 Polish National Police Accept Delivery of First Two S-70i Black Hawk Helicopters, December 3, 2018, https://www.pzlmielec.pl/en/media/news/art,136,polish-national-police-accept-delive ry-of-first-two-s-70i-black-hawk-helicopters.html (accessed February 2, 2018).

16 Third Black Hawk for the Polish National Police, November 20, 2018, https://www.pzlmielec. $\mathrm{pl} / \mathrm{en} / \mathrm{media} /$ news/art,135, third-black-hawk-for-the-polish-national-police.html (accessed February 2, 2019).

17 Brudziński: jednym z naszych priorytetów było zwiększenia bezpieczeństwa Polaków, December 5, 2018, https://www.pap.pl/aktualnosci/news\%2C369435\%2Cbrudzinski-jednym-z-na szych-priorytetow-bylo-zwiekszanie-bezpieczenstwa (accessed February 2, 2019). 
the purchases made by the Police. ${ }^{18}$ In 2018, they planned to buy over a thousand cars $^{19}$, but the exact number actually purchased is not yet publically known. ${ }^{20}$ This is of great importance in the context of deficiencies that the Supreme Audit Office has noted. In its report published in January 2018, it was stated that in 2016 there was a shortage of more than six hundred such vehicles. ${ }^{21}$

These purchases would not have been possible if not for "The Programme for modernization of the Police, Border Guard, State Fire Service and State Protection Service in the years 2017-2020", which was established in December 2016. In 2018 it was decided to increase the total amount of expenditure for the implementation of the programme, from 9.186 billion PLN to 9.208 billion PLN. ${ }^{22}$ In addition, the purchase of many police cars was co-financed by local governments.

Some of the Police investments were related to the organization of the United Nations Climate Change Conference (COP24), which took place in Katowice. This was the biggest event for the security institutions in 2018, requiring many months of preparation and exercises, the involvement of $8 \%$ of all Polish police officers and extensive coordination efforts. In connection with securing COP24, Poland temporarily reinstated border controls (from November 22 to December 16) and introduced the first (the lowest) level of terrorist alert (ALFA). The operation, codenamed "Climate 2018", was successful; there were no serious security breaches during the summit. ${ }^{23}$

Other police services made noticeable purchases as well. For example the Border Guard signed a contract for the supply of the H135 helicopter produced by Airbus Helicopters. The transaction will be financed by the "Programme". ${ }^{24}$ Some

18 Nowe radiowozy w polskiej policji, December 4, 2018, https://mojafirma.infor.pl/moto/wiadomosci/wydarzenia/2825985, Nowe-radiowozy-w-polskiej-policji.html (accessed February 2, 2019).

19 Brudziński: jednym z naszych priorytetów...

20 Interpelacja $n r 27811$ do ministra spraw wewnętrznych i administracji w sprawie taboru samochodowego Policji, November 20, 2018, https://www.sejm.gov.pl/Sejm8.nsf/InterpelacjaTresc. xsp?key=B6SEQ3\&view=null (accessed February 2, 2019).

21 Użytkowanie samochodów służbowych przez funkcjonariuszy Policji, Najwyższa Izba Kontroli, Warszawa, January 2018, p. 7.

22 Ustawa $z$ dnia 22 listopada 2018 r. o zmianie ustawy o ustanowieniu „Programu modernizacji Policji, Straży Granicznej, Państwowej Straży Pożarnej i Służby Ochrony Państwa w latach 20172020”, Dziennik Ustaw 2019, item 88.

23 Operacja „Klimat 2018” zakończona, December 18, 2018, https://www.csp.edu.pl/csp/aktual nosci/4034,Operacja-Klimat-2018-zakonczona.html (accessed February 2, 2019).

24 E. Gajews ska, Podpisanie umowy na dostawe śmigłowca Airbus Helicopters, October 30, 2018, https://www.strazgraniczna.pl/pl/aktualnosci/7090,Podpisanie-umowy-na-dostawe-smiglow ca-AIRBUS-HELICOPTERS.html (accessed February 2, 2019). 
significant investments were co-financed by the EU's Internal Security Fund. That was the case with, for example, the purchase of 140 vehicles for the Border Guard. ${ }^{25}$ Another important change regarding the security of Poland's borders took place in November, when a contract for the implementation of automated border control systems (ABC) was signed. In 2019 passengers with biometric passports will be able to use biometric gates at the two Warsaw airports. ${ }^{26}$

The aforementioned Bureau of Anti-terrorist Operations (BOA) was reorganized in November 2018, but the new regulations would come into force in April and July 2019. The Central Counter-terrorist Unit of the Police BOA will become separated from the General Police Headquarters. BOA will be directly subordinate to the Chief Commander of the Police. It is a part of a larger organizational change, with the counterterrorist forces becoming the sixth type of the service within the Police, after criminal, investigative, internal, preventive and the support-providing ones. Together with 17 independent counter-terrorist units (one in each of the voivodships and additional one in the capital city of Warsaw), the BOA will serve as a counter-terrorist service "responsible for conducting counterterrorism activities" and "supporting the activities of the Police organizational units in conditions of particular danger or requiring the use of specialized forces, resources and tactics". ${ }^{27}$

A remaining, serious problem for some of the services, especially the Police, the Border Guard and the State Protection Service (see 4.1.), is the number of unfilled vacancies. Despite a pay rise ${ }^{28}$ and extensive promotional efforts in the media, ongoing recruitment not only failed to eliminate the problem, it did not even reduce it. As of the $31^{\text {st }}$ of December, 2018, there were 4,598 vacancies (4.45\%) for Police officers. A year earlier the number was 4,588 (4.44\%). The main obstacle in employing new officers is not the shortage of resources, but the lack of suitable candidates. The Police remains a popular employer, but in 2018 only one in four candidates successfully passed through the qualification process. ${ }^{29}$ The

25 A. Michalska, Samochody ze środków FGW, December 20, 2018, https://www.strazgraniczna. $\mathrm{pl} / \mathrm{pl} /$ aktualnosci/7241,Samochody-ze-srodkow-FGW.html (accessed February 2, 2019).

26 M. Pietraszczyk, Bramki biometryczne ABC na polskich lotniskach, November 30, 2018, https://www.strazgraniczna.pl/pl/aktualnosci/7182,Bramki-biometryczne-ABC-na-polskich-lotniskach.html (accessed February 2, 2019).

27 Ustawa $z$ dnia 9 listopada 2018 r. o zmianie ustawy o Policji oraz niektórych innych ustaw, Dziennik Ustaw 2019, item 15.

28 Systematycznie podnosimy wynagrodzenia w stużbach podległych MSWIA, March 27, 2018, https://www.policja.pl/pol/aktualnosci/156734,Systematycznie-podnosimy-wynagrodzenia -w-sluzbach-podleglych-MSWiA.html (accessed February 12, 2019).

29 Liczba policjantów w polskiej Policji - fakty, January 10, 2019, https://www.policja.pl/pol/aktual nosci/168231,Liczba-policjantow-w-polskiej-Policji-fakty.html (accessed February 12, 2019). 
problem became the subject of an anonymous petition addressed to the Sejm, which proposed to enable foreigners to serve in the Police. ${ }^{30}$ As expected, the petition was rejected. The vacancies in the Border Guard are even more of a problem: as of the $30^{\text {th }}$ of November, 2018, there were 1,221 (7.61\%). ${ }^{31}$

\subsection{The uniformed services protest}

2018 will be remembered as a time of nationwide protest by the uniformed services. Although in May the least-paid officers received increases, their scale and amount did not satisfy the demands. After months of expressing dissatisfaction, in July the Federation of Trade Unions of the Uniformed Services, consisting of the unions of the Police, the Prison Service, the Border Guard, the State Fire Service, and the Customs and Tax Service, began a series of protest actions. It demanded, among other things, a pay rise and return to the previous, more favourable pension system, which was in force until the end of $2012 .{ }^{32}$

The Police limited the issuing of fines, which reduced budget revenues. Then, on the $2^{\text {nd }}$ of October, about 30,000 Police officers, firemen, border guards and prison guards protested in Warsaw. The demonstration was called the largest in the history of the Polish uniformed services. ${ }^{33}$ Then came the biggest event of the protest. Because police officers, border guards and prison guards are not legally entitled to strike, the protesters reached for a controversial measure, with many of them taking sick leave. The exact number remains unknown, but the General Police Headquarters estimated that at the beginning of November about 30,000 Police officers, i.e. about $30 \%$ of their total number, were absent from duty due to sick leave. ${ }^{34}$ The date of the action was not accidental, as National Independence Day (11 November) and celebration of the centenary of Poland regaining its independence were approaching. Due to the scale of the action, it would have been impossible to effectively secure the ceremonies. The protests proved to

30 Petycja $w$ sprawie nowelizacji Ustawy o Policji, www.orka.sejm.gov.pl/petycje.nsf/nazwa/145417-18/\$file/145-417-18.pdf (accessed February 12, 2019).

31 Sytuacja kadrowa $w$ stużbach MSWiA. Stan na 1 grudnia 2018, https://www. nszzp.pl/aktu alnosci/sytuacja-kadrowa-w-sluzbach-mswia-stan-na-grudzien-2018/ (accessed February 20, 2019).

32 Uchwały Federacji Związków Zawodowych Stużb Mundurowych, July 11, 2018, https://www. zzsflorian.pl/images/aktualnosci/2018/2018_07_13/2018_07_11_uchwaly_Rada_Federacji_ ZZ_SM.pdf (accessed February 12, 2019).

33 L. Kostrzewski, Policja grozi L4, “Gazeta Wyborcza”, October 22, 2018.

34 Rzecznik ZUS: Zakład nie ma uprawnień do kontroli zwolnień lekarskich policjantów, November 8, 2018, https://www.gazetaprawna.pl/artykuly/1339349,rzecznik-zus-zaklad-nie-mauprawnien-do-kontroli-zwolnien-lekarskich-policjantow.html (accessed February 2, 2019). 
be effective, and the Minister of the Interior and Administration was forced to sign an agreement with representatives of the uniformed services he oversees. It covered an increase in salaries and more favourable retirement conditions. ${ }^{35}$ Similar agreements were then signed with other protestors, representing security institutions subordinated to the Minister of Justice (the Prison Service) and the Minister of Finance (the Customs and Tax Service). ${ }^{36}$

The opportunity created by the protest was not taken advantage of by producing a comprehensive framework of wage regulation in the security institutions, as the agreement was limited to simply satisfying the specific financial demands being made during the protest. Salaries are still set individually for each institution; there is no specified linkage between salaries and the types of duties carried out. No objective guidelines indicate how much employees of specific uniformed services earn in relation to each other. It is also worth pointing out that no demands regarding changes in the organization of work, for example concerning ineffective statistics-oriented policing, were formulated by the protesters.

\subsection{The transposition of the Police Directive}

The so-called Police Directive of the European Union was passed on the $27^{\text {th }}$ of April, 2016. ${ }^{37}$ It is considered to be "a second part" of the General Data Protection Regulation. Regulations and directives are different types of EU legal acts. The former are binding for all EU countries and do not need to be transposed into national law. The latter establish specific results which the EU member states are obligated to meet, but give them a free hand in choosing the methods for achieving them. Failure to implement the directive may result in infringement proceedings being taken by the European Commission.

35 P. Malinowski, Protest policjantów. Związkowcy porozumieli się z MSWiA, November 8, 2018, https://www.rp.pl/Sluzby-mundurowe/181109413-Protest-policjantow-Zwiazkowcyporozumieli-sie-z-MSWiA.html (accessed February 2, 2019).

36 J. Bereźnicki, Związkowcy z KAS rezygnuja z protestu. Rząd ugiąt się pod żądaniami podwy$\dot{z} e k$, November 21, 2018, https://www.money.pl/gospodarka/wiadomosci/artykul/zwiazkowcy-z-kas-rezygnuja-z-protestu-rzad,17,0,2422033.html (accessed February 2, 2019).

37 Directive (EU) 2016/680 of the European Parliament and of the Council of 27 April 2016 on the protection of natural persons with regard to the processing of personal data by competent authorities for the purposes of the prevention, investigation, detection or prosecution of criminal offences or the execution of criminal penalties, and on the free movement of such data, and repealing Council Framework Decision 2008/977/JHA, "Official Journal of the European Union”, no. L 119, May 4, 2016. 
The purpose of the directive is to ensure "a high level of protection of personal data" of EU citizens in relation to preventing and combating crime. The EU member states had two years from the date of the directive's entry into force in which to implement it - the deadline was the $6^{\text {th }}$ of May, 2018. ${ }^{38}$ The government presented a draft version of the act implementing the directive in mid-April, but it was not until the end of August that the Council of Ministers decided to send it to the parliament. The act was officially submitted to the Sejm on the $30^{\text {th }}$ of October. ${ }^{39}$ It was passed on by the Sejm on the $14^{\text {th }}$ of December and the president signed it on the $8^{\text {th }}$ of January, 2019. The act will come into force on the $6^{\text {th }}$ of February, 2019, precisely nine months after the deadline. The other EU member states had similar problems with punctuality ${ }^{40}$, but the case of Poland was significant as it was yet another example of the fact that the implementation of European surveillance regulations meets with resistance in the country.

The bill regulates the rules for the processing and protecting of personal data, and the rights of data subjects. The scale of the implementation of the directive raises a number of issues. Firstly, the fundamental dispute concerns the fact that the Polish secret services were excluded from the act. ${ }^{41}$ The government standpoint is that this is consistent with the directive, which states that "activities concerning national security, activities of agencies or units dealing with national security issues and the processing of personal data by the Member States when carrying out activities which fall within the scope of Chapter 2 of Title V of the Treaty on European Union", entitled "Specific provisions on the common foreign and security policy", should not be considered "to be activities falling within the scope" of the Police Directive. ${ }^{42}$ This interpretation is problematic because, as the Polish Commissioner for Human Rights pointed out, "not all statutory duties carried out by the secret services fall within the scope of the term 'national security"'. ${ }^{43}$ Secondly, oversight of the processing of personal data is to be carried out by presidents of the courts, the National Council of the Judiciary and

38 Ibidem.

39 Rzadowy projekt ustawy o ochronie danych osobowych przetwarzanych w zwiazku z zapobieganiem i zwalczaniem przestępczości, the Sejm paper no. 2989, October 30, 2018.

40 Transposition of the Directive (EU) 2016/680. State of play in the Member States - February 2018, https://www.ec.europa.eu/transparency/regexpert/index.cfm?do=groupDetail.groupMeet ingDoc\&docid=12946 (accessed February 2, 2019).

41 Ustawa $z$ dnia 14 grudnia 2018 r. o ochronie danych osobowych przetwarzanych w zwiazku $z$ zapobieganiem i zwalczaniem przestępczości, Dziennik Ustaw 2019, item 125.

42 Directive (EU) 2016/680 of the European Parliament and of the Council...

43 Krytyczna opinia RPO dla Senatu co do ustawy, która ma wdrażać unijna „dyrektywe policyjną", December 20, 2018, https://www.rpo.gov.pl/pl/content/Krytyka-RPO-dla-senatu-ustawy-odanych-osobowych-ws-dyrektywy-policyjnej-UE (accessed February 2, 2019). 
the prosecutors at the appropriate level. ${ }^{44}$ This begs the question of the regulation's compliance with the EU's stance that the member states should establish "supervisory authorities" overseeing the processing of personal data with "complete independence". ${ }^{45}$ Thirdly, classified information has been exempted from the provisions of the act. Such a wide deviation from the principles introduced by the directive can be regarded as inconsistent with its general assumptions. ${ }^{46}$

\section{THE SECRET SERVICES}

\subsection{Budget, staff, equipment and organizational changes}

The Polish secret services cost slightly over PLN 1.5 billion in 2018. Out of the five, only the 2018 budget of the Foreign Intelligence Agency was decreased (by $1.5 \%$ ). The budget of the Internal Security Agency went up by $4 \%$ and the budgets of the other three intelligence agencies were increased significantly: the Military Counterintelligence Service by $12 \%$, the Central Anti-Corruption Bureau by $25 \%$ and the Military Intelligence Service by $38 \%{ }^{47}$ The numbers are presented in the chart below.

Figure 2. The comparison of secret services' budgets in 2017-2018 (in millions PLN)

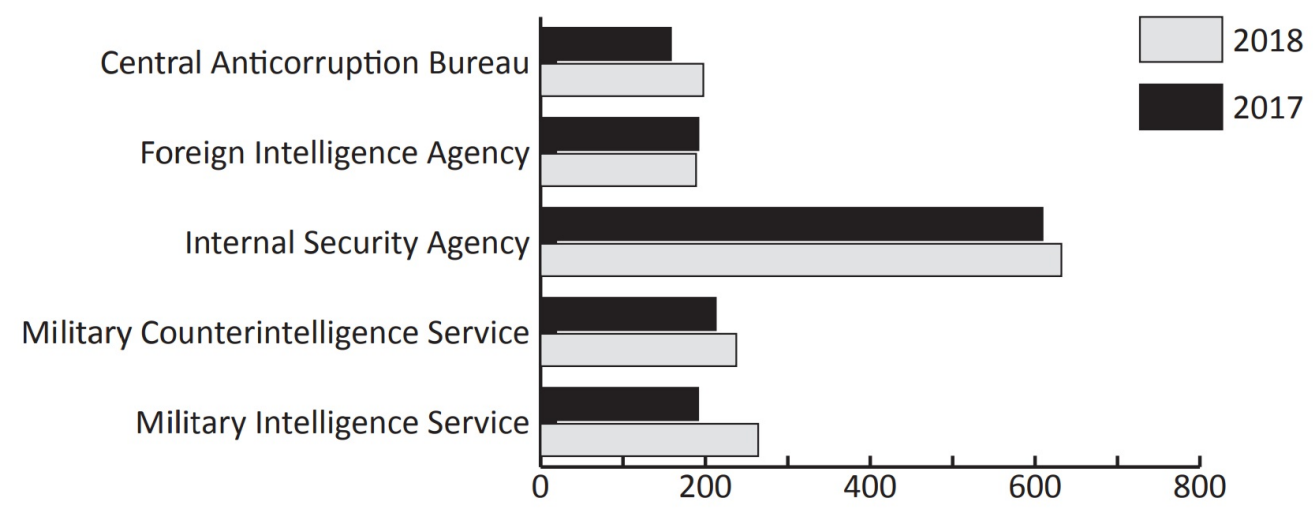

Source: Ustawa budżetowa na rok 2017...; Ustawa budżetowa na rok 2018...

44 Ustawa $z$ dnia 14 grudnia 2018 r. o ochronie danych osobowych...

45 Krytyczna opinia RPO dla Senatu...

46 Ibidem.

47 Ustawa budżetowa na rok 2017...; Ustawa budżetowa na rok 2018... 
Details of the exact number of people employed by the Polish intelligence and counterintelligence institutions are not available to the public. Among the secret services, the most transparent in this area is the Central Anticorruption Bureau, which publishes annually a report containing employment data. The 2018 report was not yet available at the time of writing. However, even without these data it is known that all of the secret services are looking for new employees. For this purpose the Foreign Intelligence Agency has even started an online promotional campaign. ${ }^{48}$

In 2018 the public got to know the structure of the Foreign Intelligence Agency, which has been classified since 2011. Currently, it consists of nine departments: the Operational Department; the Information Department; the Technical Department; the Security Office; the Finance and Administrative Office; the Personnel and Training Office; the Legal Office; the Cabinet of the Head; and the Independent Department for Crisis Management. ${ }^{49}$

In May 2018 the Terrorism Prevention Centre of Excellence (TPCoE) was established within the structure of the Internal Security Agency. The official opening of the TPCoE was held on the $22^{\text {nd }}$ of May. ${ }^{50}$ The Center carries out tasks in four priority areas: terrorism prevention, international cooperation, analytical and expert support, and information strategy. It aims at "shaping the security culture" by building counterterrorist "awareness in society". Other asymmetrical threats are also within the scope of the Center. The TPCoE will be responsible for organizing "tailored training for officers and employees of secret services, as well as public administration bodies and other entities". The organizers see it as "an important step toward institutionalization and facilitation of the cooperation" within Three Seas Initiative, consisting of Austria, Bulgaria, Croatia, Czech Republic, Estonia, Hungary, Latvia, Lithuania, Poland, Romania, Slovakia and Slovenia. ${ }^{51}$

48 See for example Agencja Wywiadu - Wizerunek, January 12, 2018, https://www.youtube.com/ watch? $=$ whAGdO15XSE (accessed February 12, 2019).

49 Zarządzenie nr 106 Prezesa Rady Ministrów z dnia 3 lipca 2018 r. zmieniające zarządzenie w sprawie nadania statutu Agencji Wywiadu, Monitor Polski 2018, item 660.

50 Opening of TPCoE - Warsaw, https://tpcoe.gov.pl/cpe/events/3,Opening-of-TPCoE-Warsaw. html (accessed February 2, 2019).

51 Mission. Shaping the Security Culture by Building CT Awareness in Society, https://tpcoe.gov.pl/ cpe/about-us/1,MISSION.html (accessed February 2, 2019). 


\subsection{Surveillance procedures}

Although in 2018 there was yet another extension of the surveillance competences of the Polish security institutions (this time of the National Revenue Administration), the most important event in this area was one which did not take place.

At the beginning of 2018 the Constitutional Tribunal was due to present the results of the assessment of the compliance of the so-called Polish Surveillance Act, i.e. the Act of 15 January 2016 amending the Police Act and certain other acts, with the constitution. The Act caused great controversy upon its creation, and it has become one of the most discussed topics in the media. The scale of its interference in individual privacy rights and the effectiveness of control and supervision of the processing of personal data it has introduced have caused serious concern. An application to examine the compliance of its provisions with the fundamental law was made in February 2016 by the Commissioner for Human Rights. Also, in 2016 a number of other provisions of fundamental importance for human rights were adopted, for example the act on the "fruits of the poisoned tree" in criminal proceedings and the antiterrorism law. The Commissioner expressed his doubts about their provisions as well, filing six applications with the Constitutional Tribunal. ${ }^{52}$

However, the Constitutional Tribunal did not issue a ruling concerning the surveillance act, as the Ombudsman withdrew his application. Between March and December 2018, the Commissioner withdrew a total of six of his applications. He argued that the change of the formation of the court had no legal basis (it was changed from the full bench to a five-person bench) and that two judges should not be a part of the formation, as they were appointed to the Tribunal via an infringement of the constitution (the so-called 'anti-judges'). ${ }^{53}$ The composition and functioning of the Tribunal, as well as its independence from the political elite, have been the subject of dispute since the 2015 Polish constitutional court crisis. Agnieszka Grzelak, the director of the Commissioner's office, stated that though those issues remain unresolved, "the road via Constitutional Tribunal is almost impossible now" ${ }^{54}$

52 A. Nyzio, Wokót „ustawy inwigilacyjnej”. Geneza, przepisy i konsekwencje Ustawy z dnia 15 stycznia 2016 r. o zmianie ustawy o Policji oraz niektórych innych ustaw, "Jagielloński Przegląd Bezpieczeństwa” 2017, no. 1, p. 68.

53 Ibidem, pp. 69-70.

54 A. Grzelak, Choosing between two Evils: the Polish Ombudsman's Dilemma, Verfassungs Blog, May 6, 2018, https://verfassungsblog.de/choosing-between-two-evils-the-polish-om budsmans-dilemma/ (accessed February 2, 2019). 
This issue is of great importance in the context of the increasing scale of the surveillance activities undertaken by Polish security institutions. Although exact numbers on data retention and operational control in 2018 are not yet available, the partial information provided by the largest telecommunications companies indicates that the trend continues to grow. The chart below presents the number of requests concerning users/accounts submitted by the Polish security institutions in the first half of 2018. Data for the first half of 2017 are presented for comparison.

Figure 3. Total number of users (accounts) specified in the government's request

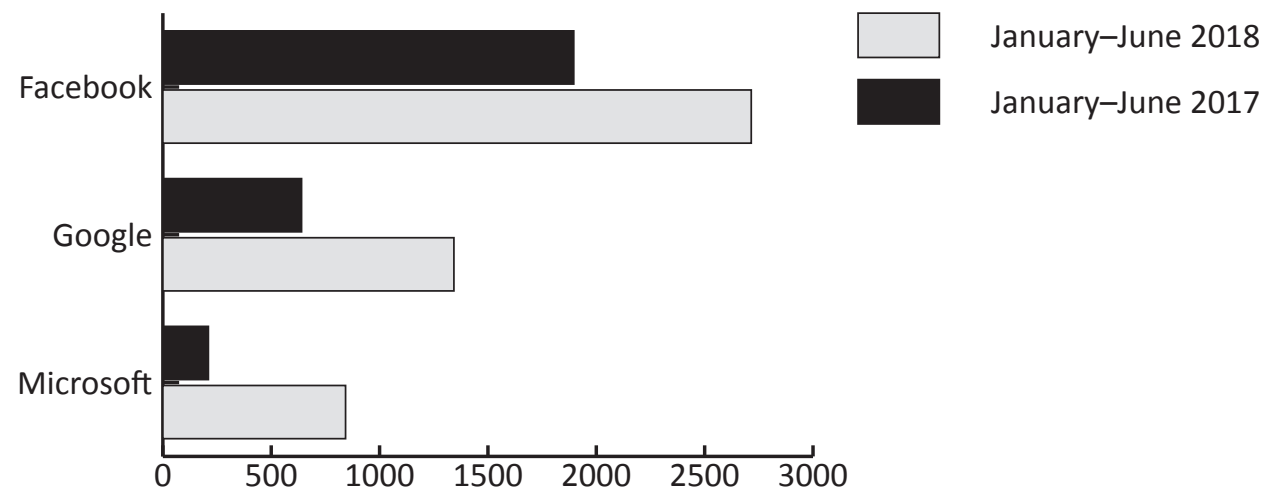

Source: Facebook transparency, at https://transparency.facebook.com/government-datarequests/country/PL (accessed February 2, 2019); Google transparency, at https://transpar encyreport.google.com/user-data/overview (accessed February 2, 2019); Microsoft corporate responsibility, at https://www.microsoft.com/en-us/corporate-responsibility/lerr/ (accessed February 2, 2019)

Information on the number of wiretaps authorized in 2018 will be published in the late spring, and information on telecommunications, postal and internet data that has been processed by the Polish security institutions in 2018 will be made available to the public in the summer. 


\section{The NeW INSTITUtions}

\subsection{The State Protection Service}

In 2018 the Government Protection Bureau (GPB), a police service responsible for the protection of the state's officials for more than sixty years, was disbanded. Thus the ruling Law and Justice party acted upon a proposal from its 2014 manifesto, fulfilling one of its most important promises in the field of internal security. The party had criticized the Bureau for years, accusing it of a lack of professionalism, mismanagement and, above all, negligence contributing to the Smolensk plane catastrophe in 2010. The government argued that the audit conducted on the Bureau in December 2015 exposed major organizational pathologies and the lack of a vision for institutional development..$^{55}$ The act establishing the State Protection Service (SPS) was passed on the $8^{\text {th }}$ of December, 2017. The president signed the act on the $9^{\text {th }}$ of January, 2018, and on the $1^{\text {st }}$ of February it came into force.

The State Protection Service is the direct successor of the Government Protection Bureau, as its structures and most of its personnel have been transferred to the new service. The main difference between the two is related to the wider tasks and competences with which the State Protection Service has been equipped. In relation to the tasks carried out by the Bureau, the number of people and objects protected by the institution was increased. Not only are the facilities of the president, the prime minister, the interior minister and the foreign minister now protected, but also those used by the other members of the Council of Ministers. Therefore, the SPS replaced the private security companies which had hitherto protected some government properties. ${ }^{56}$

The most important change, however, concerns the right to conduct operational and investigative activities, including operational control, which the $\mathrm{Bu}$ reau lacked. The SPS's predecessor conducted only "preventive actions", which were partially similar but carried out on a smaller scale. Authorizing the State Protection Service to conduct operational and intelligence activities, i.e. surveillance, opened the debate on its actual status. Due to this change and the overwhelming secrecy surrounding its functioning, some have recognized the SPS

55 Odpowiedźna interpelacjęnr 27082 wsprawiestrukturformacji Stużba Ochrony Państwa, December 12, 2018, https://www.sejm.gov.pl/sejm8.nsf/InterpelacjaTresc.xsp?key=B7EK44\&view= 1t (accessed February 2, 2019).

56 Rządowy projekt ustawy o Stużbie Ochrony Państwa z projektami aktów wykonawczych, the Sejm paper no. 1916, October 10, 2017. 
as the sixth Polish secret service. In the functional or institutional sense, this is certainly a reasonable argument, but in the legal sense the matter is clear - the legislator considers it to be a police service.

The setting up of the SPS lasted until the end of April 2018. The reform enabled major personnel changes, as the transfer of staff between the GPB and the SPS was not carried out automatically. Until the end of March 2018, the chief of the State Security Service was responsible for deciding which officers and employees of the Government Protection Bureau would be invited to join the new institution. The average number of officers employed by the GPB was 2210, and the SPS is to have bigger staff. In 2017 there were 1966 officers in the GPB; the goal for the SPS is to achieve an employment level of 3,000 officers by the end of the year 2022. It was planned to employ 165 officers in 2018, which would bring the staff number closer to the mid-term point of $2375 .{ }^{57}$ However, it turned out that the new institution is struggling with a major staffing problem. By the $1^{\text {st }}$ of December 219 people had decided to leave the service. In mid-2018, 1932 officers were employed, which meant that the number of vacancies was around $19 \% .^{58}$ Later, the Deputy Minister of the Interior and Administration, responsible for overseeing the SPS, declared that 108 Police officers, 8 Border Guard officers, 34 officers of the Prison Service and 2 officers of the Customs and Tax Service had been transferred to the new institution. ${ }^{59}$ As of the $1^{\text {st }}$ of December, 1,990 officers served in the SPS. ${ }^{60}$

In the budget for 2018, PLN 237 million was allocated to the GPB and the SPS. ${ }^{61}$ The total cost of the reform of the institution in 2018-2027 will amount to not more than PLN 3.34 billion. $^{62}$

57 Ibidem.

58 Odpowiedź na interpelację nr 22652 w sprawie delegowania funkcjonariuszy innych służb mundurowych do służby w Stużbie Ochrony Państwa, July 24, 2018, https://www.sejm.gov.pl/sejm8. nsf/InterpelacjaTresc.xsp?key=B2ZHEZ\&view=1t (accessed February 2, 2019).

59 Odpowiedź na interpelację nr 27609 w sprawie przechodzenia funkcjonariuszy do służby w SOP, December 12, 2018, https://www.sejm.gov.pl/Sejm8.nsf/InterpelacjaTresc.xsp?key=B7FJWT (accessed February 2, 2019).

60 Odpowiedź na interpelację $\mathrm{nr} 27082 \ldots$

${ }_{61}$ Ustawa budżetowa na rok 2018...

${ }^{62}$ Rządowy projekt ustawy o Stużbie Ochrony Państwa... 


\subsection{The Internal Oversight Inspector and the Internal Oversight Office}

The establishment of the Internal Oversight Office is another example of an idea of the Law and Justice that was carried out in 2018. The party has called for years for a strengthening of the supervision procedures over the uniformed services, arguing that in order for the units responsible for this to work effectively it is necessary to strengthen their independence. Furthermore, the party emphasized that it is essential to increase and specify the supervisory competences of the minister responsible for internal affairs. To this end, in the spring of $2017 \mathrm{a} \mathrm{draft}$ of the act amending the act on specific forms of supervision by the minister was created. The act establishing the position of the Internal Oversight Inspector and the Internal Oversight Office was passed on the $9^{\text {th }}$ of November, 2017. The president signed the act on the $28^{\text {th }}$ of December, 2017, and on the $27^{\text {th }}$ of January, 2018, it came into force. ${ }^{63}$

The Internal Oversight Inspector is appointed by the minister responsible for internal affairs and directly subordinate to him. The main objective of the Inspector is to support the minister in exercising his supervision of the relevant services. The position of the Office in the system of state organs and institutions may seem misleading. It is a new security institution, but not a new security service. Strictly speaking, the Office is an organizational unit of the Ministry of the Interior and Administration. Its purpose is to provide organizational support for the Internal Oversight Inspector's statutory tasks. The Office was granted competence to conduct operational and investigative activities, but these are narrow in scope: both objectively (limited to corruption offenses and organized crime) and subjectively (limited to Police officers, border guards, officers of the State Protection Service and the State Fire Service, and other employees of these services). Internal affairs units functioning within the Police and the Border Guard have been separated within the structure of those institutions to become organizational units. Their chiefs were granted the status of organs, similar to the status of the commander of the Central Bureau of Investigation of the Police. ${ }^{64}$

63 Ustawa z dnia 9 listopada 2017 r. o zmianie ustawy o niektórych uprawnieniach pracowników urzędu obsługujacego ministra właściwego do spraw wewnętrznych oraz funkcjonariuszy i pracowników urzędów nadzorowanych przez tego ministra oraz niektórych innych ustaw, Dziennik Ustaw 2018, item 106.

64 Ibidem. 


\subsection{The National Cybersecurity System}

On the $5^{\text {th }}$ of July, 2018, the Sejm passed the Act on the National Cybersecurity System, which came into force on the $28^{\text {th }}$ of August. ${ }^{65}$ It introduced yet another subsystem to Poland's national security, after the National Firefighting Rescue System (functioning since 1995), Civil Defence (in its current form since 1997), the Emergency Medical Services (2006), and Crisis Management (2007). The act implemented the EU's directive on security of network and information systems ${ }^{66}$ and defined the organization of the system, the tasks and duties of its elements and the scope of the Cybersecurity Strategy of the Republic of Poland. The system consists of twenty types of entity, including operators and key service providers, research institutes, the National Bank of Poland, the Government Plenipotentiary for Cybersecurity and the Council for Cybersecurity, with the last of these being created by the act. ${ }^{67}$ The position of the Plenipotentiary, which plays the key role in the system, was filled in December $2018 .{ }^{68}$ The setting up of the new institution came to an end, but the system is yet to become fully operational.

\section{Conclusions}

The year 2018 was not as decisive for Polish internal security as 2016 had been. The changes introduced in this period are above all a continuation of previous efforts. The policy of the Law and Justice-led government in this area remains consistent. It is worth emphasizing the importance of the EU, which either forced some of the changes or contributed to their financing. The views of the Polish legislators and government on security remain unchanged, and a consensus prevails between the most important political parties. In fact, there is not much to

65 Ustawa z dnia 5 lipca 2018 r. o krajowym systemie cyberbezpieczeństwa, Dziennik Ustaw 2018, item 1560.

66 Directive (EU) 2016/1148 of the European Parliament and of the Council of 6 July 2016 concerning measures for a high common level of security of network and information systems across the Union, "Official Journal of the European Union”, no. L 194, July 19, 2016.

67 Ibidem.

68 Premier powołał Karola Okońskiego na stanowisko Pełnomocnika Rządu do spraw Cyberbezpieczeństwa, December 7, 2018, https://www.gazetaprawna.pl/artykuly/1382629,premier-powo lal-karola-okonskiego-na-stanowisko-pelnomocnika-rzadu-do-spraw-cyberbezpieczenstwa. html (accessed February 2, 2019). 
say about the opposition's actions, as it does not offer any proposals for far-reaching changes to the security policy. On the one hand, this means that the system is stable and predictable. On the other, however, it signifies that the problems that have been visible for years are probably here to stay.

\section{BIBLIOGRAPHY}

203/CUT/18/EJ/PMP, przetargi.policja.pl/zp/archiwum-1/2018/161673,203Cut18EJPMP. html (accessed February 12, 2019).

272/CTR/18/TJ/PMP, przetargi.policja.pl/zp/postepowania-o-zamowie/164959,272Ctr 18TJPMP.html (accessed February 12, 2019).

Agencja Wywiadu - Wizerunek, January 12, 2018, https:/www.youtube.com/ watch?v=whAGdO15XSE (accessed February 12, 2019).

Bereźnicki, J. Związkowcy z KAS rezygnuja z protestu. Rzad ugiąt się pod żadaniami podwyżek, November 21, 2018, https://www.money.pl/gospodarka/wiadomosci/arty kul/zwiazkowcy-z-kas-rezygnuja-z-protestu-rzad,17,0,2422033.html (accessed February 2, 2019).

Brudziński: jednym z naszych priorytetów było zwiększenia bezpieczeństwa Polaków, December 5, 2018, https://www.pap.pl/aktualnosci/news\%2C369435\%2Cbrudzinskijednym-z-naszych-priorytetow-bylo-zwiekszanie-bezpieczenstwa (accessed February 2,2019$)$.

Directive (EU) 2016/1148 of the European Parliament and of the Council of 6 July 2016 concerning measures for a high common level of security of network and information systems across the Union, "Official Journal of the European Union", no. L 194, July 19, 2016.

Directive (EU) 2016/680 of the European Parliament and of the Council of 27 April 2016 on the protection of natural persons with regard to the processing of personal data by competent authorities for the purposes of the prevention, investigation, detection or prosecution of criminal offences or the execution of criminal penalties, and on the free movement of such data, and repealing Council Framework Decision 2008/977/JHA, "Official Journal of the European Union”, no. L 119, May 4, 2016.

Gajewska, E. Podpisanie umowy na dostawe śmigłowca Airbus Helicopters, October 30, 2018, at https://www.strazgraniczna.pl/pl/aktualnosci/7090,Podpisanie-umowy-nadostawe-smiglowca-AIRBUS-HELICOPTERS.html (accessed February 2, 2019).

Grzelak, A. Choosing between two Evils: the Polish Ombudsman's Dilemma, VerfassungsBlog, May 6, 2018, https://verfassungsblog.de/choosing-between-two-evilsthe-polish-ombudsmans-dilemma/ (accessed February 2, 2019).

Interpelacja $n$ r 27811 do ministra spraw wewnętrznych i administracji $w$ sprawie taboru samochodowego Policji, November 20, 2018, https://www.sejm.gov.pl/Sejm8.nsf/In terpelacjaTresc.xsp?key=B6SEQ3\&view=null (accessed February 2, 2019). 
Jarosław Zieliński: Do 2020 powstana 43 nowe posterunki policji, February 5, 2018, https://www.portalsamorzadowy.pl/wydarzenia-lokalne/jaroslaw-zielinski-do2020-powstana-43-nowe-posterunki-policji,103665.html (accessed February 2, 2019).

Kostrzewski, L. Policja grozi L4, “Gazeta Wyborcza”, October 22, 2018.

Krytyczna opinia RPO dla Senatu co do ustawy, która ma wdrażać unijna „dyrektywę policyjna”, December 20, 2018, https://www.rpo.gov.pl/pl/content/Krytyka-RPOdla-senatu-ustawy-o-danych-osobowych-ws-dyrektywy-policyjnej-UE (accessed February 2, 2019).

Liczba policjantów w polskiej Policji - fakty, January 10, 2019, https://www.policja.pl/ pol/aktualnosci/168231,Liczba-policjantow-w-polskiej-Policji-fakty.html (accessed February 12, 2019).

Malinowski, P. Protest policjantów. Związkowcy porozumieli się z MSWiA, November 8, 2018, https://www.rp.pl/Sluzby-mundurowe/181109413-Protest-policjantow-Zwiaz kowcy-porozumieli-sie-z-MSWiA.html (accessed February 2, 2019).

Michalska, A. Samochody ze środków FGW, December 20, 2018, https://www.strazgra niczna.pl/pl/aktualnosci/7241,Samochody-ze-srodkow-FGW.html (accessed February 2, 2019).

Mission. Shaping the Security Culture by Building CT Awareness in Society, https://tpcoe. gov.pl/cpe/about-us/1,MISSION.html (accessed February 2, 2019).

Nowe radiowozy w polskiej policji, December 4, 2018, https://mojafirma.infor.pl/moto/ wiadomosci/wydarzenia/2825985, Nowe-radiowozy-w-polskiej-policji.html (accessed February 2, 2019).

Nyzio, A. Wokół „ustawy inwigilacyjnej”. Geneza, przepisy i konsekwencje Ustawyz dnia 15 stycznia 2016 r. o zmianie ustawy o Policji oraz niektórych innych ustaw, "Jagielloński Przegląd Bezpieczeństwa” 2017, no. 1, p. 68.

Odpowiedź na interpelację nr 22652 w sprawie delegowania funkcjonariuszy innych służb mundurowych do służby w Służbie Ochrony Państwa, July 24, 2018, https://www. sejm.gov.pl/sejm8.nsf/InterpelacjaTresc.xsp?key=B2ZHEZ\&view=1t (accessed February 2, 2019).

Odpowiedź na interpelację nr 27082 w sprawie struktur formacji Służba Ochrony Państwa, December 12, 2018, https://www.sejm.gov.pl/sejm8.nsf/InterpelacjaTresc.xsp ?key=B7EK44\&view=1t (accessed February 2, 2019).

Odpowiedź na interpelacje nr 27609 w sprawie przechodzenia funkcjonariuszy do stużby $w$ SOP, December 12, 2018, https://www.sejm.gov.pl/Sejm8.nsf/InterpelacjaTresc. xsp?key=B7FJWT (accessed February 2, 2019).

Opening of TPCoE - Warsaw, https://tpcoe.gov.pl/cpe/events/3,Opening-of-TPCoEWarsaw.html (accessed February 2, 2019).

Operacja „Klimat 2018” zakończona, December 18, 2018, https://www.csp.edu.pl/csp/ aktualnosci/4034,Operacja-Klimat-2018-zakonczona.html (accessed February 2, 2019).

Petycja w sprawie nowelizacji Ustawy o Policji, www.orka.sejm.gov.pl/petycje.nsf/ nazwa/145-417-18/\$file/145-417-18.pdf (accessed February 12, 2019). 
Pietraszczyk, M. Bramki biometryczne ABC na polskich lotniskach, November 30, 2018, https://www.strazgraniczna.pl/pl/aktualnosci/7182,Bramki-biometryczne-ABC-napolskich-lotniskach.html (accessed February 2, 2019).

Polish National Police Accept Delivery of First Two S-70i Black Hawk Helicopters, December 3, 2018, https://www.pzlmielec.pl/en/media/news/art,136,polish-national -police-accept-delivery-of-first-two-s-70i-black-hawk-helicopters.html (accessed February 2, 2018).

Ponad dwa tysiace kamer osobistych trafi do policjantów, 26 July 2018, https://www.po licja.pl/pol/aktualnosci/161930,Ponad-dwa-tysiace-kamer-osobistych-trafi-do-poli cjantow.html (accessed February 2, 2019).

Premier powołał Karola Okońskiego na stanowisko Petnomocnika Rządu do spraw Cyberbezpieczeństwa, December 7, 2018, https://www.gazetaprawna.pl/artyku ly/1382629, premier-powolal-karola-okonskiego-na-stanowisko-pelnomocnika-rza du-do-spraw-cyberbezpieczenstwa.html (accessed February 2, 2019).

Realizacja programu modernizacji służb mundurowych na półmetku, February 6, 2019, www.policja.pl/pol/aktualnosci/169260,Realizacja-Programu-Modernizacji-SluzbMundurowych-na-polmetku.html (accessed February 6, 2019).

Rozporządzenie Ministra Spraw Wewnętrznych i Administracji z dnia 11 października 2018 r. zmieniajace rozporzadzenie $w$ sprawie wykroczeń, za które strażnicy straży gminnych sq uprawnieni do nakładania grzywien $w$ drodze mandatu karnego, Dziennik Ustaw 2018, item 1996.

Rządowy projekt ustawy o ochronie danych osobowych przetwarzanych $w$ zwiazku $z$ zapobieganiem i zwalczaniem przestępczości, the Sejm paper no. 2989, October 30, 2018.

Rządowy projekt ustawy o Służbie Ochrony Państwa z projektami aktów wykonawczych, the Sejm paper no. 1916, October 10, 2017.

Rzecznik ZUS: Zakład nie ma uprawnień do kontroli zwolnień lekarskich policjantów, November 8, 2018, https://www.gazetaprawna.pl/artykuly/1339349,rzecznik-zuszaklad-nie-ma-uprawnien-do-kontroli-zwolnien-lekarskich-policjantow.html (accessed February 2, 2019).

Straż miejska może karać mandatem za łamanie uchwały antysmogowej, portal Samorządowy.pl, November 2, 2018, https://www.portalsamorzadowy.pl/prawo-i-finanse/ straz-miejska-moze-karac-mandatem-za-lamanie-uchwaly-antysmogowej,116124. html (accessed December 12, 2018).

Systematycznie podnosimy wynagrodzenia w służbach podległych MSWIA, March 27, 2018, https:/www.policja.pl/pol/aktualnosci/156734,Systematycznie-podnosimy-wy nagrodzenia-w-sluzbach-podleglych-MSWiA.html (accessed February 12, 2019).

Sytuacja kadrowa w stużbach MSWiA. Stan na 1 grudnia 2018, https://nszzp.pl/aktu alnosci/sytuacja-kadrowa-w-sluzbach-mswia-stan-na-grudzien-2018/ (accessed February 20, 2019).

Third Black Hawk for the Polish National Police, November 20, 2018, https://www.pzl mielec.pl/en/media/news/art,135,third-black-hawk-for-the-polish-national-police. html (accessed February 2, 2019). 
Transposition of the Directive (EU) 2016/680.State of play in the Member States - February 2018, https://ec.europa.eu/transparency/regexpert/index.cfm?do=groupDetail. groupMeetingDoc\&docid=12946 (accessed February 2, 2019).

Uchwały Federacji Związków Zawodowych Służb Mundurowych, July 11, 2018, https:// www.zzsflorian.pl/images/aktualnosci/2018/2018_07_13/2018_07_11_uchwaly_ Rada_Federacji_ZZ_SM.pdf (accessed February 12, 2019).

Ustawa budżetowa na rok 2017 z dnia 16 grudnia 2016 r., Dziennik Ustaw 2017, item 108. Ustawa budżetowa na rok 2018 z dnia 11 stycznia 2018 r., Dziennik Ustaw 2018, item 291. Ustawa z dnia 5 lipca 2018 r. o krajowym systemie cyberbezpieczeństwa, Dziennik Ustaw 2018, item 1560 .

Ustawa z dnia 9 listopada 2017 r. o zmianie ustawy o niektórych uprawnieniach pracowników urzędu obsługującego ministra właściwego do spraw wewnętrznych oraz funkcjonariuszy i pracowników urzędów nadzorowanych przez tego ministra oraz niektórych innych ustaw, Dziennik Ustaw 2018, item 106.

Ustawa z dnia 9 listopada 2018 r. o zmianie ustawy o Policji oraz niektórych innych ustaw, Dziennik Ustaw 2019, item 15.

Ustawa $z$ dnia 14 grudnia 2018 r. o ochronie danych osobowych przetwarzanych $w$ zwiazku z zapobieganiem i zwalczaniem przestępczości, Dziennik Ustaw 2019, item 125.

Ustawa z dnia 22 listopada 2018 r. o zmianie ustawy o ustanowieniu „Programu modernizacji Policji, Straży Granicznej, Państwowej Straży Pożarnej i Służby Ochrony Państwa w latach 2017-2020”, Dziennik Ustaw 2019, item 88.

Użytkowanie samochodów służbowych przez funkcjonariuszy Policji, Najwyższa Izba Kontroli, Warszawa, January 2018, p. 7.

Weber, M. Bezpieczeństwo to sprawa gminy, October 1, 2018, https://www.rp.pl/Prawodla-samorzadow/310039907-Bezpieczenstwo-to-sprawa-gminy.html\&cid=44\& template $=$ restricted (accessed February 2, 2019).

Zarządzenie Nr 69 Prezesa Rady Ministrów z dnia 29 sierpnia 2012 r. w sprawie powołania Międzyresortowego Zespołu do spraw Współpracy ze Strażami Gminnymi (Miejskimi), Monitor Polski 2012, item 631.

Zarządzenie nr 106 Prezesa Rady Ministrów z dnia 3 lipca 2018 r. zmieniające zarzadzenie w sprawie nadania statutu Agencji Wywiadu, Monitor Polski 2018, item 660.

Zarządzenie nr 200 Prezesa Rady Ministrów z dnia 28 listopada 2018 r. w sprawie zniesienia niektórych organów pomocniczych Rady Ministrów i Prezesa Rady Ministrów, Monitor Polski 2018, item 1191.

Żółciak, T. Minister Błaszczak szykuje rewolucję w strażach miejskich, Forsal.pl, June 28, 2017, https://forsal.pl/artykuly/1053813,minister-blaszczak-szykuje-rewolucje-wstrazach-miejskich.html (accessed February 20, 2018). 